\title{
Socio- Political, Economic and Cultural Life in the Cauvery Belt during the First Half of $18^{\text {th }}$ Century
}

\author{
Seethalakshmi V. \\ Department of History, Seethalakshmi Ramaswami College, Tiruchirapalli-2, Tamilnadu
}

\begin{abstract}
The first half of $18^{\text {th }}$ century $A D$ has been an interesting and important period in the history of Tamilnadu, especially of the Cauvery belt. It had its ramifications on the rest of India later.

A study of the period in all its aspects - political, economic, social and cultural and spiritual reveals certain interesting contradiction at the surface level. While the period in general was marked by unending wars. Political instability, heavy taxes, neglect of agriculture and commerce and frequent famines, it also witnessed cultural, literary and spiritual renaissance of some sort. Several saintly persons from this region belong to this era. There had also been a renewed interest in music and literature during this period. How this has been made possible will form the subject matter for a much larger study, since poets, singers and saints generally live on the society and if economics and politics are not healthy state, their survival becomes that much difficult and to find a pattern or a purpose behind all these contradictions will be an even more interesting challenging assignment.
\end{abstract}

Key words: Cauvery belt, Political instability, spiritual renaissance

\section{Political Scenerio:}

Thanjavur, Trichirappalli, Ramnad, and Pudukkottai were the major seats of power in the region at that time. Nearly two decades before the beginning of the eighteenth century, around 1674 AD, the Naik dynasty in Thanjavur ended and the Marathas,led by Ekoji,the half brother of shivaji, came to power. Ramnad (Ramanathapuram) was then under the sethupathis-literally meaning the Lords of sethu(Rameshwaram)-who enjoyed autonomy under the nayaks of Madurai (and Trichirappalli).Kilavan Sethupathi (1671-1710) of Ramnad. In addition ,in1686 AD, he gave his brother- in - law Ragunatha Raya Tondiman a piece of land from his booty, comprising of the fort of pudukkottai and surrounding areas and thus brought legitimacy to the fledging stets of Pudukkottai. In Madurai, Rani Mangammal died in about 1706 A.D and was succeeded by her grandson Vijayaranga Chokkanatha Nayaka, who preferred to the rule from Trichirappalli, The kings of Trichi, Thanjavur and Ramnad were always fighting against one anoher, often any two joining against the third. Pudukkottai generally acted as a mercenary, serving one or the other kings at war depending upon its own interests.

These were not only powers in the scenario. There were the Maraths and the Nawab of Arcot to contend with. Though Shivaji died in 1680 AD, the Maratha empire was in the ascendancy and was always eager to poke its nose in other's affairs. Similarly, though Aurangazeb died in 1707 AD, marking the beginning of the decline of the Mughal empire, Zulfirkhar khan , his representatives was already entrenched in Tamilnadu, as the Nawab of the Carnatic, with his seat at $\operatorname{Arcot}(1692 \mathrm{AD})$. His first target was the Senjee fort and after several attempts, he finally captured it in 1698 and drove out Rajaram, the son of shivaji, who had sought asylum there at the time. Having captured Senjee, the Nawab was naturally eager to expand his territory and meddle in the affairs of the kingdoms in the south.

Then there were the Europeans, the Portuguese, the Dutch and the Danish were on the decline at that time but the British and the French were fighting their proxy wars through the local kings to establish their hegemony in India. The turning point was in the year $1752 \mathrm{AD}$, when Chanda Sahib was killed in Trichi and the British, under Robert Clive, scored their first significant victory against the French, led by Dupleix . In the next fifty years, the entire Tamilnadu came under their control and the Polygar resistance from deep South was the last act of resistance to the British from Tamilnadu.

A similar situation prevailed in Bengal and gave the British another foothold in India. Soon the British extended their control to the entire country, which lasted until 1947 AD.

This in short is the political history of the first half of the $18^{\text {th }}$ century in the Cauvery belt. In addition to the main plot, there have also been several interesting sub-plots from the period. For example, Nawab Zulfirkhan of Arcot appointed Tej Singh (Raja Desingu) as the governor of Senjee in 1700 in good faith. However, Tej Singh rebelled against Zulfikhar's successor Nawab saadetullah and became independent. He fought a battle against the Nawab in 1713 died a heroic death. Tej Singh's wife committed Sati later.Popular ballads are sung about Raja Desingu till date. 
Another sub-plot pertains to Rani Minakshi of Tiuchi. After Chokkanatha Nayak's death in 1731, his wife Meenakshi acted as a regent on behalf of their adopted son, who was ruling over Madurai and Tirunelvelli, wanted the Trichirappalli throne. He sought the help of Safdar Ali Khan, the son of the then Arcot Nawab and promised him 3 million rupees as bribe. Safdar Ali Khan took a bond for the said amount, declared Bangaru Thirumala as the king and went back to Arcot leaving Chanda Sahib, the Nawab's nephew to implement the agreement reached in any way he wanted. The Queen Minakshi in turn bribed Chanda Sahib one million rupees to declare her as the duly entitled queen. Chanda Saheb agreed and swore on a copy of Quran. But the Queen got tricked since, it was not really a copy of Quran but a brick, wrapped in a splendid covering, usually meant for Koran. The disappointed Bangaru Thirumala went back to rule over Madurai and Thirunelveli.

Chanda Sahib later soon came back to Trichirappalli as the queen's guest,marched on to the South,defeated Bangaru Thirumal Naik and drove him out. He had no use for Minakshi anymore and so he put her in jail. The woman committed suicide by taking poison. With that,the Naik rule came to an end in Madurai/Trichirappalli.

Chanda sahib's own story is equally interesting. He ruled Trichirappalli for five years . Then in 1740, The Marathas defeated him and took him as a prisoner to Satara in Maharastra. In 1743, the Hyderabad Nizam's army took Trichirappalli back from the Marathas and Trichirappalli came under the rule of Arcot Nawab.

In 1748, Chanda sahib was released by the Marathas. He came back to Tamilnadu and killed the Arcot Nawab in 1749 in a fierce battle and became the Nawab. He also formed an alliance with the Frenchman Dupliex. The original Nawab's son, Muhammad Ali Wallajah , fled to Tiruchirappalli and proclaimed himself the Nawab from there and naturally sought the help of the British. The second Carnatic war(1749-1754) soon broke out. In 1751 Chanda sahib, with the help of the French, attacked Muhammad Ali who was inside Trichirappalli and killed by Clive's forces in 1752. His head was removed and rest of the body was buried in a Dargah in Trichirappalli.

At the same period, Karnataka was being ruled by a succession of wodeyars. During 1749, in Krishnaraja Wodeyar II's period, a mercenary soldier, Haider Ali, a descendant of a wandering Islamic Fakir, Came to the notice of the king. Haider ali soon cleverly made himself indispensable to the King and kept him under his control for the next 12 years. In fact, he took over the regins of Bangalore in 1759 after the Wodeyar was forced to gift him the area. Hyder Ali and later his son Tipu Sultan, supported by the French, fought against the British and lost.

While a few kings were benevolent and tried to mitigate the difficulties of their citizens during such circumstances, there were also tyrants and their unscruplos officials who were only interested in filling up their coffers at any cost.

Famines were frequent, as a result. For example, a terrible famine occurred in the Pudukkottai in 1709 which lasted till 1713. It is belived that only one-thirtieth of the population survived the disaster. The price of rice rose 32 times to its original level. Since, the distribution system was practically non-existent, the deficiencies in one region were never made up from the plenty from another region. The Entire period in short was one of untold misery to the public.

\section{Saints From The Period:}

The Period also witnessed the advent of several saints. A study of the lives and legends of saints goes by the name hagiology and there is no dearth of such literature in India.Often, such literature contain very little of historical facts and describes several improbable miracles wrought by the saints. Though an extact count of such persons is impossible, there is reason to believe that they were not in short supply. Some of the well-known names amongst them are Sadasiva Brahmendra, Gopalakrishna Sastri, Sridhara Venkatesa or Ayyaval, Saint Thayumanavar, Bhaskara Raya, Abirami Bhattar and Narayana Thirtha.Table-1 contains brief details about their birth and deaths.

\begin{tabular}{|l|l|l|l|l|l|}
\hline S.No & Name & $\begin{array}{l}\text { Birth Year- } \\
\text { (Lower Limit) }\end{array}$ & $\begin{array}{l}\text { Death Year- } \\
\text { (Upper Limit) }\end{array}$ & Birth-Place & $\begin{array}{l}\text { Samadhi/ } \\
\text { Death-Place }\end{array}$ \\
\hline 1 & Sadasiva Brahmendra & $1700^{*}$ & $1760^{* *}$ & Madurai & Nerur \\
\hline 2 & Gopalakrishna Sastri & $1690^{*}$ & 1762 & Bikshandarkoil & Namanasamudram \\
\hline 3 & $\begin{array}{l}\text { Sridhara Venkatesa } \\
\text { (Ayyaval) }\end{array}$ & $1640^{*}$ & $1740^{*}$ & Andra & Thiruvidaimarudur \\
\hline 4 & Thaymanavar & 1707 & 1783 & Trichirappalli & RamanathaPuram \\
\hline 5 & Bhaskara Raya & 1690 & 1785 & Maharastra & Baskararayapuram \\
\hline 6 & Abirama Bhatar & 1670 & 1770 & Thirukadaiyur & Thirukadaiyur \\
\hline 7 & Narayana Tirtar & 1675 & 1745 & Andra & Varahur \\
\hline
\end{tabular}

Of them, Sadasiva Bramendra was a great yogi, Scholar, recluse and a composer before he became a mouni. He is credited with several philosophical works of which yogasudh Akara, Atma vidhya vilasa and 
Advaita rasa manjan are the more popular ones. About 23 kirthanas composed by him are also currently available. He is said to have attained Jeeva Samadhi in Nerur, near Karur of his own volition. Among the innumerable miracles credited to him, one deserves a mention.

The saint was once roaming on the banks of Cauvery near Trichirappalli. One Muslim king was also camping near the place with his harem. Sadasiva Brahmendra, totally bereft of body conscience, casually walked through the harem in his natural state. The enraged nawab took a long sword and cut off the Right hand of the sage. The sage, unmindful of his physical condition was moving on nonchalantly. The nawab was amazed. He took the felled hand to the saint and requested him to pardon him. The sage touched his maimed shoulder with his left hand and a new limb grew in its place immediately.

There is no mention about the identity of the king but Jackson ${ }^{1}$ thinks that it could be Chanda Saheb.

However, there are enough references about the saint in history. His meeting with Vijayaragunatha Thondaiman in 1738 in Thiruvarangulam near Pudukkottai is well-documented. The sage initiated the king through a mantra during the meeting and advised him to take Goplalakrishna Sastri as his preceptor, which the king did. Sastri had been a friend and a classmate of the sage in his younger days. Similarly, Serfoji -I sent an emissary by name Mallari Pandit to meet the Sage when the sage was in Dipampuram and the subsequent report of the emissary to the king is available in literature.

Gopalakrishna Sastri was a great scholar in Sanskrit grammar and became the palace guru at Pudukkottai due to Sadasiva's wishes. Sastri descendants continued to be the Palace Gurus until 1947.Sastri himself became a recluse in his old age and his body after death is buried in a Samadhi in Namanasamudram near Pudukkottai.Sastri is well-known for his work called Sabthika Chinthamani, a commentary on Panini's Ashtadhyai. He has to his credit a few other works as well.

Sridhara Venkatesa(or Ayyaval) lived in Thiruvisainallu, near Kumbakonam. The Maratha king shaji renamed it a Shajirajapuram in 1692 and brought more than 50 scholars from all over his kingdom and made them live there by bequeathing lands to them. Sridha Venkatesa has composed a Sanskrit work called Sahendra Vilasam in praise of Shaji. He had also composed several devotional works in Sanskrit. He is supposed to have made the river Ganges flow from the well in his backyard, the anniversary of which is being celebrated in Thiruvisainallur till date.

Thayumanavar, the famous Tamil poet and saint was in the court of Chokkanatha Nayak in Trichirappalli and after the king's death, continued in the services of Rani Minakshi for some time. He soon left the palace and became a wandering mendicant and his end came in a place near Ramanathapuram.

Bhaskararaya is actually a Maharshtrian, who shifted to Tamilnadu during the period of the Maratha king Venkoji (or Ekoji), Shivaji's half-brother and Shaji's father. He was so much revered by the king that a village by name Baskararayapuram was created in his honour. Baskararaya has written exactly eight slokas in praise of shaji, which scholars claim was the forerunner to Sridhara Venkatesa's Sahendravilasam on Shaji.Baskararaya was a renowned worshipper of Devi and his fame rests on the commentary he has written for Lalitha Sahasranamam.

Abhirami Bhattar is well-known in Tmilnadu, thanks to his Abhirami Andhathi, and he lived in Thirukkadaiyur. He is supposed to have been met in the famous temple in Thirukkadaiyur by Serfoji-I, who was then on a pilgrimage to the sea, which incident is supposed to have triggered the composing of Abhirami Andhathi.

Narayana Thirtha came from Andra and settled down in Varahur near Thanjavur. His Krishna Lila Tharangini is said be the longest dance drama in Sanskrit.

These are some of the well-known names and probably there were many more saints belonging to that period. How these saints were supported by the kings and the public amidst all the wars, famines and pestilence is a matter for a deeper study.

\section{Literature:}

Though a number of compositions have appeared in Sanskrit, Telugu and even Marathi during that time, there have not been many Tamil works, due perhaps to the lack of official patronage, since none of the kings hade Tamil as his mother tongue. However, there have been lesser poets like Ambalavaana Kavirayar (Arappalisura Satakam), Gurupada Desikar(Kumaresa Sadhagam), Kachchiyappa Munivar( Thiruthangai Puranam), Madhura Kaviyirayar ( Thirukkavur Nandhinnadagam), Munaip Padiyar ( Araneri Charam), Palapaattai Sokkannaadha Pulavar (Azhagar Killaividu Thudhu), Santa Linga Kavirayar ( Thandhalaiyar Sadhagam ), Thandavaraya Swamigal ( Kaivalya Navannidham), Thirigudha Rasappak Kavirayar ( Kurralak Kuravanchi and several other works). Whether all of them lived in the Cauvery belt , remains to be studied.

The biggest name amongst them all is Sivagnana Munivar who has credit several works including Amudhambigai Pillaith Thamizh, Kalasai Padhirrupp Andhadhi, Kanysi Puranam, Thiruvida Mabadiyam , 
Thirumullai Vayil Andhadhi and Somesar Mudhumozhi Venba. Interestingly there have been several Muslim men-of-letters or Muslim themes like Vannakkalanjiya Pulavar ( Mungirn Malai),following the tradition set by Umaru Pulavar, who composed seera Puranam in the previous century.

This was also the period of Virama Munivar or Costanzo Giuseppe Beschi who was the Bishop of Purathakudi, near Samayapuram, Trichirappalli during the $18^{\text {th }}$ century. He is credited wih several works like Adikala Malai, Avivega Puranaguru Kadhai, Cadhuragaradhi, Thembavani, Thonnul Vilakkam. Also a special mention should be made of Ananda Rangam Pllai, a Dwibashi or a translator who was serving the French. His diaries belonging to the period 1736-1760, give a vivid historical account of the happenings of that period. It is a unique piece in Tamil Literature.

\section{MUSIC}

While any discussion about music in the Cauvery belt invariably leads to the Carnatic Music Trinity of Tyagaraja, Muthuswami Dikshitar and Syama Sastri , it must be borne in mind that they belong to the latter half of the $18^{\text {th }}$ Century and a musical tradition was already in place when they were born.

A special mention should be made of the Trinity of Tamil Music- Muthuthandavar, Marimutha Pillai and Arunalchala Kavirayar.

Of the three, Muthu Thandavandar belongs to an even earlier period. Marimutha Pillai (1712-1787) was a genius, who started composing at a very early age. His son was supposed to have been insane and as per folklore, Lord Nataraja Commanded him to come to Chidambaram and compose poems in praise of Him , Which Pillai faithfully did. It is also said that when Pillai authored the "Puliyoor Venba", his son's insanity is said to have been cured.

Arunachala Kavirayar (1711-1778) was a great scholar of Kamba Ramayanam and he composed his magnam opus," Rama Nataka Keerthanaigal" on the same theme. The tradition says that when he wanted to present his work in Srirangam, the locals said that he had to seek Lord Ranganathan's permission first. At this , the poet sang his famous piece "En Palli Kondeerrayya", which moved the Lord himself and it seems. He ordered the temple officials to arrange for the premiere. Apart from Rama Natakam, he has authorized several other literary works like, "Ajamukhi Natakam", Anumar Pillai Tamizh", Sirkzhi Sthala Puranam " and " Sirkazhi Kovai".

Though nothing is with any finalized about Oothukkadu Venkatasubbaiyar, there is one school of thought which says that he lived from 1700 to 1765 , while another school is emphatic that he hardly lived for 32 years. Some also push his date to the $17^{\text {th }}$ Century. However it is commonly agreed that he was a great composer and a rare devotee of Lord Krishna. Nearly 400 of his composition have been unearthed till date, which should put him on par with the musical Trinity.

It has already been seen that Sadasiva Brahmendra was a composer in his own right. In addition , Pallava Gopala Iyer( $17^{\text {th }}-18^{\text {th }}$ centuries), who composed many varnams in popular ragas and Papavinasa Mudhaliar, who composed Kumbhessar Kuravanji and was patronized by Tulaja II, Vijayagopalaswami and Mutrubhutayya are notables from the musical world belonging to the region and the period.

Matrubhutayya was a native of Trichirappalli and an ardent devotee of Sugandh Kundambika , presiding deity of the Rockfort temple. His devotional songs are collectively known as,"Sugandhi Kundalambankita Kirtanas" and "Trisiragiri Padas". He is said tio have introduced the concept of "Chittaswara" in his composition and the Anandabhaviravi raga used by him was a forerunner to the later versions. He has also composed an opera, Parijitapaharana Nataka".

\section{Larger Picture}

An interesting area which deserves to be explored is the lifestyale of Tamilians during those troubled periods and their attitude especially to politics visa- vis the other aspects of their lives. Were they indifferent to politics or did they take an active part in the affairs of their kings? Did they turn to the saints, poets and singers as a kind of escapism or were they a mature lot whose value system was on a strong foundation? Did for example, Sadasiva or Gopalakrishna Sastri advise the Pudukkottai Rajas to support the British or were their advices only confined to spiritual matters? There are many such interesting questions, the answers to which can be found only through a sustained research in this area.

\section{Conclusion}

It is unfortunate that an interest period of Tamilnadu's history has not been researched to the extent it deserves. After all, the purpose of historical research is to collect, preserve and interpret facts. Only that the facts are to be assimilated in a meaningful sequence, interpreting the facts. Some enterprising person will surely address these issues in future and come up with some interesting observations and interpretations. 


\section{References}

[1] Jackson,William J.(ed.), The Power of the Sacred Name : V. Raghavan's Studies in Namasiddhanta and Indian Culture, Sri Satguru Publication- a Division of India Books Centre, 1994.

[2] K.A.Nilakanda Sastry, History of South India , from Prehistoric times to fall of Vijayanagar, 1955,OUP, (Reprinted 2002) ISBN 019560686-8.

[3] Atma vidhya Vilasa - palm leaf manuscript written by Sadasiva himself and given to Serfoji-I Saraswathi Mahal Library.

[4] Thiruvengadathan.Ramabhadra Dikshita and His works-A study: Pub.by the Kuppuswami Satri Research Institute,84,Royapettah High Road, Chennai-600004.

[5] Raghavan, V.1952.Sahendravilasa: A Poem on the life of King Sahaji of tanjore(1684-1710) of Sridhara Venkatesa (Ayyaval). Tanjore Maharaja Serfoji's Saraswathi Mahal Library.

[6] Sabtika Chintamni Mahabashyam gopalakrishna Sastri R143( University Oriental Library-Forwards by Mahatma Gandhi, Published by G.A.Natesan \& Co,Madras , 1938

[7] 'Prayers, Praises and Pslams',by Dr.V.Raghavan, Madras University, PP . 455 \& 456 with a forewrad by Mahatma Gandhi, Published by G.A.Natesan \& co,Madras. 1938.

[8] Sastri,T.S.Kuppuswamy. 1904. "Ramabhadra Dikshita and the Sourthern Poets of his Time" Indian Antiquary 33:126-42;176-96.

[9] Mallari Pandit's Letter to serfoji- I aboput Sadsiva at Dipampuram, sadasiva Bramendra's Minor works. Vani Villas Press, Srirengam.

[10] Sri Krishna Leela Tharangini of Narayana Theertha- vol I \& II published by Sri Narayanatheertha Educational and charitable Trust , Madras - 28 (1987). 